\title{
Digestion of alfalfa and grass silages in sheep. 2. Digestion of protein in reticulorumen and intestines
}

J. van Bruchem ${ }^{1}$, A. K. Kies ${ }^{1,2}$, R. Bremmers ${ }^{1,2}$, Marlou W. Bosch ${ }^{1}$, H. Boer $^{2}$ and P. W. M. van Adrichem ${ }^{1}$

1 Department of Animal Physiology, Wageningen Agricultural University, Haarweg 10, NL 6709 PJ Wageningen

2 Department of Animal Nutrition, Wageningen Agricultural University, Haagsteeg 4, NL 6708 PM Wageningen, Netherlands

Received 5 August 1987; accepted 6 September 1988

Key words: rumen protein degradability, rumen microbial protein synthesis, true protein digestibility, DAPA, amino acid profile

\begin{abstract}
Wilted alfalfa and grass silages were fed to mature wethers. Estimates of degradability of proteins in the reticulorumen were lower with DAPA (38-71\%) than based on amino acid profiles of dietary, microbial and duodenal proteins (64$87 \%$ ). Microbial protein synthesis was closely related to extent of organic matter fermentation in the reticulorumen. Efficiency of protein synthesis hardly differed between silages. Apparent digestibility of protein and amino acids in the small intestine was lower for the alfalfa silage $(54 \%)$ in comparison with the grass silages (60-63\%), probably caused by a higher dry matter passage in the small intestine with the least digestible alfalfa silage. Relative to the amino acid profiles of milk protein and beef, histidine and methionine seemed to be the first limiting (semi-) essential amino acids.
\end{abstract}

\section{Introduction}

In ruminants, the supply of amino acids for maintenance and production depends on various factors. Crude protein ingested is only one of the determinants. Besides that, the extent of degradation of dietary protein and the rate of microbial protein synthesis in the reticulorumen are important determinants, the latter being closely related to the quantity of organic matter fermented and the $\mathrm{N}$-source available.

Amino acids are only absorbed from the small intestine, where the protein mixture leaving the compound ruminant stomach is degraded by proteolytic enzymes, emerging from pancreatic juice and small intestinal mucosa. Of microbial protein, true digestibilities in the small intestine have been reported close to $90 \%$ (van Bru- 


\section{J. VAN BRUCHEM ET AL.}

chem et al., 1985b). The net supply of amino acids, however, is more closely related to the apparent digestibility. The contrast between these two digestibility measures is caused by the quantity of endogenous protein leaving the small intestine, which in turn is related to the extent at which endogenous protein is produced in the small intestine as enzymic protein, mucoprotein and desquamated epithelial cells. It seems that the major part is digested again before reaching the ileum. The remainder is digested in the hind gut, though not resulting in a net production of amino acids.

We suggest that with increasing passages of dry matter in the small intestine the quantity of endogenous protein increases. Whether with roughage-type diets this might result in lower apparent digestibilities of amino acids, has to be investigated.

The quantity of dry matter reaching the small intestine depends on intake and digestibility, the latter being closely related to the cell wall fraction. The results of the digestive behaviour of this fraction, together with those on retention of the feed in the reticulorumen and the lower gastro-intestinal tract are reported by Bosch et al. (1988).

\section{Materials and methods}

Two experiments were conducted with four mature Texel whethers, fitted with cannulas in the rumen, the proximal duodenum and the terminal ileum, and an infusion tube in the abomasum. In Exp. I, an alfalfa (A) and a grass silage (G1) were fed ad libitum. In Exp. II, another grass silage was supplied at two feeding levels, ad libitum (G2H) and at approximately $70 \%$ of ad libitum (G2L). Amounts and composition of the diets supplied and details of experimental lay-out were as outlined by Bosch et al. (1988).

In the freeze-dried and subsequently ground samples the following analyses were carried out:

- dry matter content by drying the constant weight at $101{ }^{\circ} \mathrm{C}$;

- $\mathrm{N}$ by the Kjeldahl method with $\mathrm{K}_{2} \mathrm{SO}_{4}$ and $\mathrm{HgO}$ as catalysts;

- DAPA and the individual amino acids with a Biotronic LC6000 automatic amino acid analyser. The test sample was hydrolysed with $\mathrm{HCl} 6 \mathrm{~mol} \mathrm{l}^{-1}$ at $110^{\circ} \mathrm{C}$ for $22 \mathrm{~h}$. The sulphur-containing amino acids methionine and cystine were determined as methionine sulphone and cysteic acid, respectively, after formic acid oxidation (Moore, 1963). Tryptophan was not determined.

From samples collected from the ventral rumen sac, microbes were isolated by differential centrifugation (550-70000 $\mathrm{g}$ ) with a MSE superspeed 65 centrifuge at $4{ }^{\circ} \mathrm{C}$. The pellet was washed twice with a buffer solution according to the method described by Meyer et al. (1967). After freeze-drying the individual amino acids, including DAPA, and $\mathrm{N}$ were estimated, the latter by the micro-Kjeldahl method.

The data were analysed statistically by a two-sampled analysis of variance, taking into consideration differences between sheep and experimental periods. Exps I and II were analysed separately. Student $t$ values for testing significances can be calculated dividing contrasts between diets by SEM $\times$ SQRT (2) within experiments or SQRT $\left(\mathrm{SEM}_{\mathrm{I}}^{2}+\mathrm{SEM}_{\mathrm{II}}^{2}\right)$ between experiments (d.f. $\left.=8\right)$. 


\section{Results}

Table 1 shows the rates of passage of organic matter $(O M)$ and non-ammonia- $N$ (NAN) in the proximal duodenum. In Exp. I, duodenal flow of NAN differed not significantly between alfalfa (A) and grass (G1) silages, despite a considerable difference in $\mathrm{N}$ intake with the diet. No significant difference could be detected either between $\mathrm{G} 1$ of Exp I and G2H in Exp II, although these grass silages were consumed at more or less comparable levels of dry matter intake, and differed consistently in $\mathrm{N}$ and cell wall contents and thus digestibility.

The extent at which dietary protein was degraded in the reticulorumen and at which de novo synthesis of microbial protein took place, was determined as follows. After correcting the duodenal flow of NAN for an endogenous contribution of $2.5 \mathrm{~g}$ per kg dry matter ingested (Harrop, 1974; Siddons et al., 1982), undegraded dietary $\mathrm{N}$ was estimated from the difference between the flow of total NAN and microbial $N$. The latter was assessed whether based on DAPA in microbes isolated from the ventral rumen sac, or based on the amino acid profile (AAP) of dietary, microbial and duodenal proteins. Amino acid profiles, including the sulphur-containing amino acids but without tryptophan, were mixed by a computerized iterative procedure as described in more detail by van Bruchem et al. (1985a). The endogenous protein passing in the duodenum was not taken into account, since its composition although not accurately known, does not seem to differ grossly from amino acid composition in mean digesta (Lindsay et al., 1980). The resulting extents of dietary protein degradation and efficiencies of microbial protein synthesis are presented in Table 1. Based on DAPA, lower values were obtained than with AAP.

Despite consistent differences in silage composition, remarkable similarity was obtained in quantity of the protein entering the small intestine, presumably as a result of the major part consisting of microbial protein synthesized in the rumen (Table 2). Amino acid profiles of rumen microbes were not related to diet composition. Thus amino acid profile of the protein reaching the small intestine showed hardly variability either. In Table 3 , mean amino acid profile of rumen microbes as compared to dietary and duodenal protein is presented. In microbes, the ratio amino acid $\mathrm{N}$ : total $\mathrm{N}$ averaged 0.66 (range 0.61-0.72).

Apparent digestibility of amino acids (Table 4) differed slightly though significantly. With alfalfa silage $(\mathrm{A})$, apparent absorption was lowest $(P<0.05)$ relative to the grass silages $\mathrm{G} 1$ and $\mathrm{G} 2 \mathrm{H}$. When the grass silage $\mathrm{G} 2$ was fed at a restricted level (G2L) the course of digestion was comparable to that with the silage available ad libitum (G2H). The proportions in which the individual amino acids were apparently absorbed, was hardly related to diet composition. In Table 5, amino acid profile of ileal protein has been presented relative to that of duodenal protein. The resulting ratio's were hardly affected by composition of the supplied diets.

Amino acid composition of the protein entering the small intestine as determined in the reticulorumen by compositions and proportions of undegraded dietary and de novo synthesized microbial proteins, is modified by digestion in the small intestine. Amino acid profile of the protein reaching the ileum is a resultant of the profile of the proteins becoming available for digestion in the small intestine, the true digesti- 


\section{J. VAN BRUCHEM ET AL.}

Table 1. Intake and duodenal flow $\left(\mathrm{g} \mathrm{day}^{-1}\right)$ of organic matter $(\mathrm{OM})$ and $\mathrm{N}$ or non-ammonia $\mathrm{N}$ (NAN), extent of ruminal degradation of dietary $\mathrm{N}(\mathrm{D}, \%)$ and efficiency of ruminal microbial protein synthesis (E, g microbial $\mathrm{N} \mathrm{kg}^{-1} \mathrm{OM}$ truly digested) in the reticulorumen as based on estimates with DAPA or AAP (means of 8 observations).

\begin{tabular}{|c|c|c|c|c|c|c|}
\hline & \multicolumn{3}{|l|}{ Exp. I } & \multicolumn{3}{|l|}{ Exp. II } \\
\hline & A & G1 & $\mathrm{SEM}_{1}$ & $\mathrm{G} 2 \mathrm{H}$ & $\mathrm{G} 2 \mathrm{~L}$ & $\operatorname{SEM}_{\|}$ \\
\hline \multicolumn{7}{|l|}{ Intake } \\
\hline OM & 1088 & 1059 & & 1134 & 803 & \\
\hline N & 38.4 & 19.7 & & 41.9 & 30.1 & \\
\hline \multicolumn{7}{|l|}{ Duodenum } \\
\hline OM & 589 & 512 & $20.5^{*}$ & 458 & 338 & $12.7^{* * *}$ \\
\hline NAN & 27.7 & 28.0 & 0.67 & 30.4 & 22.6 & $0.94^{* * *}$ \\
\hline DAPA-D & 61.8 & 38.2 & $2.52^{* * *}$ & 71.0 & 69.1 & 4.70 \\
\hline$E$ & 17.6 & 19.4 & 1.56 & 18.8 & 19.7 & 2.17 \\
\hline AAP-D & 87.1 & 64.4 & $1.48^{* * *}$ & 86.4 & 84.5 & 2.45 \\
\hline$E$ & 29.1 & 25.1 & $1.14^{*}$ & 24.9 & 25.8 & 2.12 \\
\hline
\end{tabular}

${ }^{*} P<0.05 ;{ }^{* * *} P<0.001$.

Table 2. Quantity (Q, $\left.\mu \mathrm{mol} \mathrm{h}^{-1}\right)$ of protein and amino acids entering the small intestine (means of $8 \mathrm{ob}$ servations).

\begin{tabular}{|c|c|c|c|c|c|c|}
\hline & \multicolumn{3}{|l|}{ Exp. I } & \multicolumn{3}{|c|}{ Exp. II } \\
\hline & A & G1 & $\mathrm{SEM}_{1}$ & $\mathrm{G} 2 \mathrm{H}$ & $\mathrm{G} 2 \mathrm{~L}$ & $\mathrm{SEM}_{\mathrm{II}}$ \\
\hline Cys & 454 & 435 & 16.1 & 419 & 388 & 15.9 \\
\hline Asp & 4614 & 5048 & 177.6 & 5032 & 3825 & $97.2^{* * *}$ \\
\hline Met & 639 & 756 & $27.1^{*}$ & 745 & 570 & $14.7^{* * *}$ \\
\hline Tre & 2705 & 2960 & 96.2 & 2919 & 2274 & $57.7^{* * *}$ \\
\hline Ser & 3071 & 3060 & 113.1 & 2970 & 2315 & $63.7^{* * *}$ \\
\hline Glu & 4379 & 5100 & $168.5^{*}$ & 4828 & 3740 & $93.9^{* * *}$ \\
\hline Pro & 1920 & 2101 & 94.5 & 2257 & 1786 & $57.6^{* * *}$ \\
\hline Gly & 4554 & 4803 & 165.6 & 4828 & 3751 & $92.8^{* * *}$ \\
\hline Ala & 4030 & 4789 & 165.6 & 4790 & 3629 & $85.7^{* * *}$ \\
\hline Val & 3198 & 3419 & 124.0 & 3445 & 2609 & $70.1^{* * *}$ \\
\hline Ile & 2379 & 2635 & 97.0 & 2626 & 1996 & $54.4^{* * *}$ \\
\hline Leu & 3507 & 3904 & 154.4 & 4059 & 3146 & $84.3^{* * *}$ \\
\hline Tyr & 1271 & 1470 & $51.5^{*}$ & 1510 & 1159 & $32.7^{* * *}$ \\
\hline Phe & 1814 & 1991 & 69.8 & 2085 & 1597 & $43.2^{* * *}$ \\
\hline Lys & 2711 & 2861 & 113.5 & 2765 & 2107 & $59.8^{* * *}$ \\
\hline His & 768 & 769 & 30.4 & 845 & 636 & $23.4^{* * *}$ \\
\hline Arg & 1379 & 1543 & 56.0 & 1621 & 1251 & $30.7^{* * *}$ \\
\hline $\mathrm{TAA}^{1}$ & 43393 & 47644 & 1681.0 & 47764 & 36779 & $936.4^{* * *}$ \\
\hline NAN $\left(\mathrm{mg} \mathrm{h}^{-1}\right)$ & 1153 & 1167 & 28.0 & 1267 & 941 & $39.1^{* * *}$ \\
\hline
\end{tabular}

1 Total amino acids.

${ }^{*} P<0.05 ;{ }^{* * *} P<0.001$. 
Table 3. Amino acid profiles (mol per $100 \mathrm{~mol}$ amino acid) of rumen microbes (M), ration (R) and duodenal (D) protein ( $D_{H}$ for $G 2 H$ and $D_{L}$ for $\left.G 2 L\right)$.

\begin{tabular}{|c|c|c|c|c|c|c|c|c|}
\hline & \multirow[t]{2}{*}{ M } & \multicolumn{2}{|l|}{ A } & \multicolumn{2}{|l|}{ G1 } & \multicolumn{3}{|l|}{ G2 } \\
\hline & & $\mathrm{R}$ & $\mathrm{D}$ & $\mathrm{R}$ & $\mathrm{D}$ & $\mathrm{R}$ & $\mathrm{D}_{\mathrm{H}}$ & $\mathrm{D}_{\mathrm{L}}$ \\
\hline Cys & 0.68 & 0.70 & 1.04 & 0.75 & 0.91 & 0.79 & 0.88 & 1.07 \\
\hline Asp & 11.66 & 14.85 & 10.63 & 10.19 & 10.60 & 10.42 & 10.55 & 10.40 \\
\hline Met & 1.82 & 1.24 & 1.47 & 1.47 & 1.59 & 1.51 & 1.57 & 1.55 \\
\hline Tre & 6.61 & 5.09 & 6.23 & 5.59 & 6.22 & 5.15 & 6.11 & 6.18 \\
\hline Ser & 5.90 & 6.68 & 7.06 & 6.53 & 6.43 & 5.73 & 6.21 & 6.30 \\
\hline Glu & 10.84 & 6.81 & 10.09 & 8.78 & 10.70 & 8.75 & 10.07 & 10.06 \\
\hline Pro & 3.44 & 10.82 & 4.42 & 8.48 & 4.40 & 13.57 & 4.74 & 4.85 \\
\hline Gly & 9.48 & 8.85 & 10.49 & 10.20 & 10.12 & 8.91 & 10.16 & 10.25 \\
\hline Ala & 10.76 & 11.44 & 9.29 & 11.01 & 10.04 & 9.93 & 10.05 & 9.86 \\
\hline Val & 7.11 & 7.62 & 7.37 & 7.60 & 7.18 & 7.48 & 7.20 & 7.09 \\
\hline Ile & 5.72 & 4.91 & 5.50 & 4.82 & 5.53 & 4.88 & 5.50 & 5.42 \\
\hline Leu & 7.24 & 7.56 & 8.09 & 8.90 & 8.18 & 7.78 & 8.51 & 8.54 \\
\hline Tyr & 3.55 & 2.16 & 2.93 & 2.65 & 3.09 & 2.24 & 3.15 & 3.15 \\
\hline Phe & 3.80 & 3.59 & 4.19 & 4.26 & 4.17 & 4.33 & 4.37 & 4.34 \\
\hline Lys & 6.73 & 4.44 & 6.25 & 4.30 & 6.00 & 3.84 & 5.76 & 5.72 \\
\hline His & 1.33 & 1.48 & 1.77 & 1.25 & 1.62 & 1.38 & 1.76 & 1.72 \\
\hline $\operatorname{Arg}$ & 3.36 & 1.77 & 3.17 & 3.22 & 3.23 & 3.12 & 3.42 & 3.40 \\
\hline
\end{tabular}

Table 4. Apparent digestibility ( $\mathrm{AD}, \%$ ) of amino acids in the small intestine (means of 8 observations).

\begin{tabular}{|c|c|c|c|c|c|c|}
\hline & \multicolumn{3}{|c|}{ Exp. I } & \multicolumn{3}{|c|}{ Exp. II } \\
\hline & $\mathrm{A}$ & G1 & $\mathrm{SEM}_{1}$ & $\mathrm{G} 2 \mathrm{H}$ & $\mathrm{G} 2 \mathrm{~L}$ & $\mathrm{SEM}_{\mathrm{II}}$ \\
\hline Cys & 21.1 & 33.5 & $1.40^{* * *}$ & 29.2 & 34.1 & $1.34^{*}$ \\
\hline Asp & 55.4 & 62.2 & $0.92^{* * *}$ & 60.6 & 62.8 & 1.15 \\
\hline Met & 64.7 & 68.1 & $0.87^{*}$ & 65.4 & 67.8 & 1.00 \\
\hline Tre & 51.5 & 58.4 & $1.07^{* *}$ & 55.8 & 58.4 & 1.48 \\
\hline Ser & 45.8 & 57.0 & $1.30^{* * *}$ & 53.8 & 56.3 & 1.55 \\
\hline Glu & 57.3 & 62.1 & $0.84^{* *}$ & 59.1 & 62.3 & 1.08 \\
\hline Pro & 43.2 & 57.9 & $2.02^{* * *}$ & 51.2 & 54.2 & 1.59 \\
\hline Gly & 47.1 & 60.1 & $1.29 * * *$ & 57.1 & 60.6 & $0.96^{*}$ \\
\hline Ala & 55.7 & 61.8 & $1.04^{* *}$ & 60.0 & 62.3 & 1.08 \\
\hline Val & 56.3 & 64.6 & $1.12^{* * *}$ & 61.8 & 63.3 & 1.26 \\
\hline Ile & 60.1 & 67.7 & $1.32 * *$ & 64.2 & 66.3 & 1.90 \\
\hline Leu & 58.7 & 66.3 & $1.47^{* *}$ & 64.9 & 66.6 & 1.50 \\
\hline Tyr & 59.3 & 70.0 & $1.01^{* * *}$ & 67.2 & 68.9 & 1.28 \\
\hline Phe & 66.7 & 62.8 & $1.04^{*}$ & 66.1 & 68.1 & 1.19 \\
\hline Lys & 56.8 & 65.9 & $1.15^{* * *}$ & 65.9 & 67.7 & 0.93 \\
\hline His & 45.7 & 58.5 & $1.23^{* * *}$ & 57.2 & 59.0 & 1.38 \\
\hline Arg & 67.2 & 73.6 & $1.27^{* *}$ & 70.8 & 72.3 & 1.07 \\
\hline TAA & 54.4 & 62.8 & $1.06^{* * *}$ & 60.0 & 62.7 & 1.18 \\
\hline
\end{tabular}

${ }^{*} P<0.05 ;{ }^{* *} P<0.01 ;{ }^{* *} P<0.001$. 


\section{J. VAN BRUCHEM ET AL.}

Table 5. Content of amino acids in ileal protein relative to that in protein entering the small intestine (means of 8 observations).

\begin{tabular}{|c|c|c|c|c|c|c|}
\hline & \multicolumn{3}{|c|}{ Exp. I } & \multicolumn{3}{|c|}{ Exp. II } \\
\hline & A & G1 & $\mathrm{SEM}_{1}$ & $\mathrm{G} 2 \mathrm{H}$ & G2L & $\mathrm{SEM}_{\mathrm{Il}}$ \\
\hline Cys & 1.76 & 1.79 & 0.072 & 1.79 & 1.78 & 0.058 \\
\hline Asp & 0.98 & 1.02 & $0.006^{* *}$ & 1.00 & 1.00 & 0.005 \\
\hline Met & 0.78 & 0.86 & $0.013^{* *}$ & 0.88 & 0.87 & 0.012 \\
\hline Tre & 1.06 & 1.12 & $0.009^{* *}$ & 1.11 & 1.11 & 0.008 \\
\hline Ser & 1.19 & 1.16 & $0.009^{*}$ & 1.16 & 1.17 & 0.008 \\
\hline Glu & 0.93 & 1.02 & $0.008^{* * *}$ & 1.03 & 1.01 & 0.007 \\
\hline Pro & 1.25 & 1.13 & $0.026^{*}$ & 1.23 & 1.23 & 0.018 \\
\hline Gly & 1.16 & 1.07 & $0.014^{* *}$ & 1.08 & 1.06 & 0.013 \\
\hline Ala & 0.97 & 1.03 & $0.005^{* * *}$ & 1.01 & 1.01 & 0.006 \\
\hline Val & 0.96 & 0.95 & 0.006 & 0.96 & 0.98 & 0.010 \\
\hline Ile & 0.88 & 0.87 & 0.015 & 0.90 & 0.90 & 0.029 \\
\hline Leu & 0.90 & 0.90 & 0.017 & 0.89 & 0.89 & 0.016 \\
\hline Tyr & 0.90 & 0.81 & $0.012^{* * *}$ & 0.83 & 0.83 & 0.008 \\
\hline Phe & 0.82 & 0.90 & $0.012^{* *}$ & 0.86 & 0.85 & 0.007 \\
\hline Lys & 0.95 & 0.91 & $0.008^{*}$ & 0.87 & 0.86 & 0.009 \\
\hline His & 1.19 & 1.11 & $0.015^{*}$ & 1.08 & 1.09 & 0.017 \\
\hline Arg & 0.71 & 0.71 & 0.016 & 0.74 & 0.74 & 0.015 \\
\hline
\end{tabular}

* $P<0.05 ;{ }^{* *} P<0.01 ;{ }^{* *} P<0.001$.

Table 6. Amino acid profile of amino acid apparently absorbed relative to that of milk protein and beef (ratio in parentheses).

\begin{tabular}{lccc}
\hline & Absorbed & Milk $^{\mathrm{t}}$ & Beef $^{2}$ \\
Cys & 0.48 & $0.36(1.33)$ & $0.75(0.64)$ \\
Asp & 10.58 & $7.61(1.39)$ & $8.52(1.24)$ \\
Met & 1.70 & $2.21(0.77)^{*}$ & $1.99(0.85)^{*, 3}$ \\
Tre & 5.78 & $4.63(1.25)$ & $4.33(1.33)$ \\
Ser & 5.76 & $6.64(0.87)$ & $4.66(1.24)$ \\
Glu & 10.32 & $18.50(0.56)$ & $12.62(0.82)$ \\
Pro & 3.95 & $10.27(0.38)$ & $6.05(0.65)$ \\
Gly & 9.54 & $3.46(2.76)$ & $12.19(0.78)$ \\
Ala & 9.81 & $4.82(2.04)$ & $9.26(1.06)$ \\
Val & 7.39 & $7.13(1.04)$ & $6.27(1.18)$ \\
Ile & 5.89 & $5.00(1.18)$ & $5.01(1.18)$ \\
Leu & 8.90 & $9.62(0.92)^{*}$ & $8.25(1.08)$ \\
Tyr & 3.40 & $3.71(0.92)$ & $2.28(1.49)$ \\
Phe & 4.69 & $3.80(1.23)$ & $3.12(1.50)$ \\
Lys & 6.32 & $7.19(0.88)^{*}$ & $7.41(0.85)^{*}$ \\
His & 1.58 & $2.33(0.68)^{*}$ & $2.41(0.66)^{*}$ \\
Arg & 3.91 & $2.73(1.43)$ & $4.88(0.80)^{*}$ \\
\hline
\end{tabular}

1 Posati et al. (1974).

2 Lawrie (1979).

${ }^{3}$ First limiting (semi-)essential amino acids.

* $P<0.05$. 


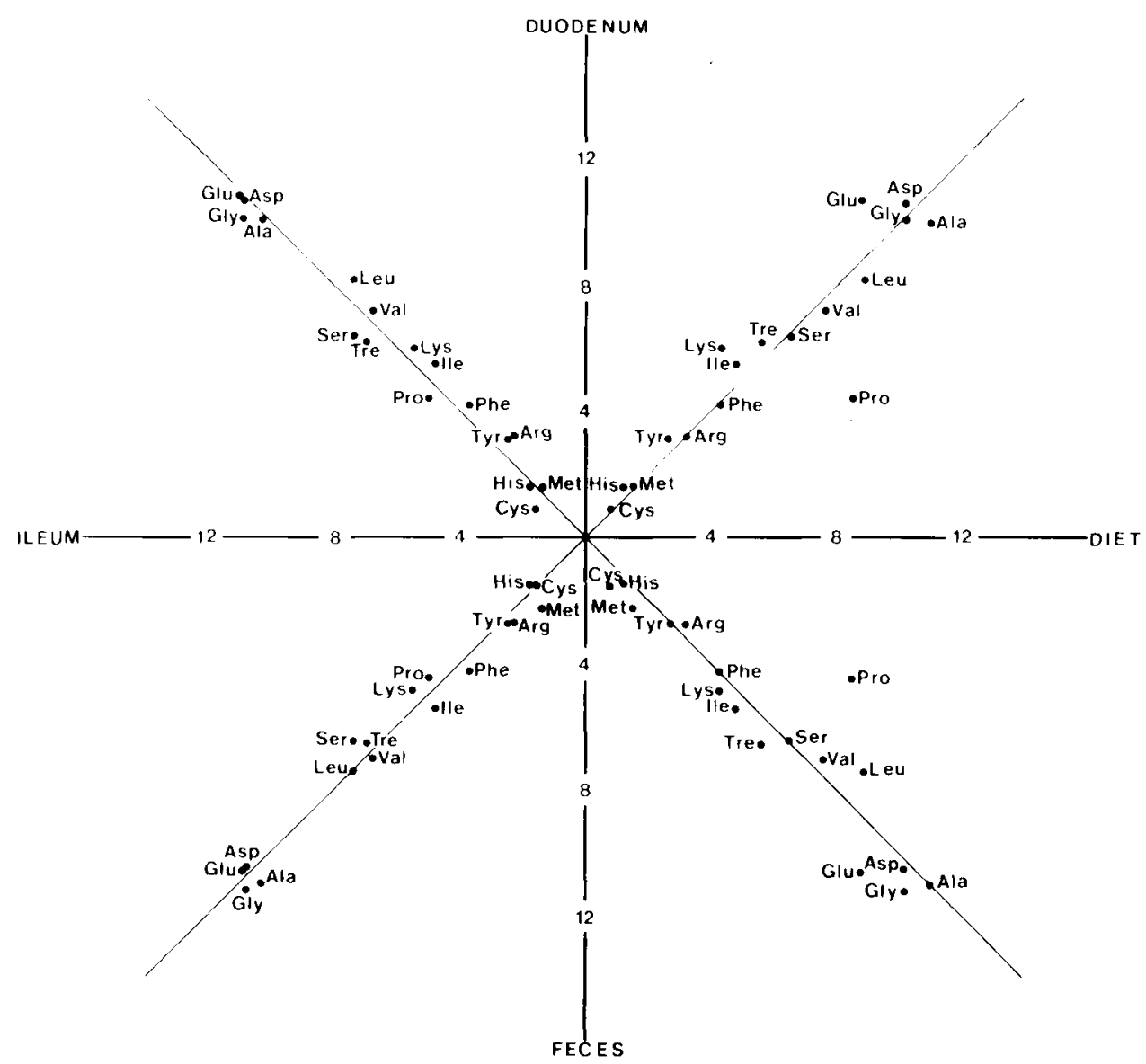

Fig. 1. Amino acid profile (mol per $100 \mathrm{~mol}$ amino acid) as evolving in the course of digestion of grass silage $(\mathrm{G} 1)$ in reticulorumen and intestines.

bility of the individual amino acids, and the quantity and composition of the endogenous protein originating from mucus, enzymatic proteins and desquamated epithelial cells. During hind gut fermentation, again amino acid profile is being modified as a result of the transition of proteins leaving the ileum into microbial protein. The way, amino acid profile is evolving in the course of the digestion process in the various gastro-intestinal compartments is, as an example for the G1 grass silage, shown in Fig. 1.

\section{Discussion}

The quantity of protein entering the small intestine did not reflect the quantities of crude protein $(\mathrm{N})$ ingested with the diet. In both silages fed in Exp. I, solubility of $\mathrm{N}$ 
proved to be high, as demonstrated in the nylon bag experiments carried out with these silages by Kwakkel et al. (1986). For A and G1 silages, N solubilities were 64.5 and $44.4 \%$, respectively. In line with these high solubilities, degradability of dietary $\mathrm{N}$ in the reticulorumen, as estimated based on the amino acid profiles (AAP) of dietary, microbial and duodenal proteins, was high as well. The lower degradabilities obtained with DAPA have most likely to be regarded as artefacts, as other examples of DAPA-based estimates of microbial protein synthesis in the rumen, which have to be regarded as less reliable (Siddons et al., 1982).

With easily degradable dietary proteins, the quantity of protein entering the small intestine is primarily determined by de novo synthesis of microbial protein in the reticulorumen, the extent at which being closely related to the quantity of organic matter fermented. Efficiency of microbial protein synthesis is amongst other factors related to the nature of the substrates fermented and the available $\mathrm{N}$ source. Next to non-protein- $\mathrm{N}$, proteins should be made available as a substrate.

From the results presented by Bosch et al. (1988), it may be deduced that after feeding these grass and alfalfa silages, $\mathrm{NH}_{3}$ concentration in rumen fluid could not be regarded as rate-limiting for microbial protein synthesis. Mean concentration was lowest for the G1 silage with the lowest crude protein content. Between feeding, $\mathrm{NH}_{3}$ concentration did not fall below $5 \mathrm{mmol} \mathrm{l}^{-1}$, a level indicated by Satter \& Slyter (1974) as sufficient for microbial protein synthesis. Between the grass silages no difference could be detected in efficiency of microbial protein synthesis. For the alfalfa silage a slightly higher $(P<0.05)$ efficiency was found. In comparison with the $\mathrm{G} 1$ silage, extent of OM digestion in the reticulorumen was lower, however, resulting in a quantity of amino acids reaching the duodenum, which did not differ significantly from $\mathrm{G} 1$.

Between diets, there were no consistent differences in relative digestibilities of individual amino acids. Thus, concentrations of amino acids in ileal protein relative to duodenal protein hardly differed between diets. So, irrespective of the silages supplied, whether grass or alfalfa silages, or grass silages with different $\mathrm{N}$ and NDF contents, or level of intake, amino acids came available for intermediary metabolism in mutually comparable ratio's.

Mean apparent digestibility of amino acids with the silages supplied ad libitum was lower in comparison with the digestibilities obtained in former experiments with roughage-concentrate rations (van Bruchem et al., 1985b), at comparable quantities of amino acids passing the small intestine. With the latter results and those of the present experiments, including some other as yet unpublished results with ryegrass straw concentrate and grass hay diets, multiple regression analysis delivered estimates of regression coefficients of ileal passage of amino acids on duodenal passage of amino acids $\left(b_{1}=0.152, \mathrm{SE}=0.016\right)$ and on ileal passage of non-protein dry matter $\left(b_{2}=0.413 \mathrm{mmol} \mathrm{g}^{-1}, \mathrm{SE}=0.038\right)$, respectively; $r^{2}$ was 0.76 . For the individual amino acids, details are published by van Bruchem et al. (1987). With the regression equation obtained for 'total amino acids' $\left(a=2.50 \mathrm{mmol} \mathrm{h}^{-1}\right)$, residues of duodenal protein passing in the ileum could be calculated, revealing estimates of true digestibility of amino acids in the small intestine of $84.8,85.3,80.3$, $83.4 \%$ for $\mathrm{A}, \mathrm{G} 1, \mathrm{G} 2 \mathrm{H}$ and G2L, respectively. These results are slightly lower 
than those published with roughage-concentrate diets (van Bruchem et al., 1985b). In those experiments, however, no correction could be carried out yet for dry matter passage in the small intestine. A true digestibility of approximately $85 \%$ is in line with the results of Storm et al. (1983) in sheep and of Hvelplund \& Madsen (1985) in cattle.

In comparison with Storm's results, however, the quantity of endogenous protein leaving the small intestine was significantly higher, even after correction for the non-protein dry matter effect. This could be caused by a decreased shedding of epithelial cells in the small intestine in sheep maintained on intragastric infusates. The present experiments revealed that an increased dry matter passage in the small intestine coincided with an increased protein flow in the ileum. This has been confirmed in experiments, in which ground ryegrass straw $\left(6.1 \mathrm{~g} \mathrm{~h}^{-1}\right)$, suspended in a $1.5 \%$ carboxymethylcellulose solution was introduced into the abomasum of sheep. As a result, with a duodenal $\mathrm{N}$ flow of $0.77 \mathrm{~g} \mathrm{~h}^{-1}, \mathrm{~N}$ flow in the mid-jejunum was increased from 0.62 to $0.73 \mathrm{~g} \mathrm{~h}^{-1}$ and in the ileum from 0.40 to $0.44 \mathrm{~g} \mathrm{~h}^{-1}$.

The ultimate prove that the dry matter effect is accomplished by an increased quantity of endogenous protein produced in the small intestine awaits further investigation, preferably with tracers. An increased passage of fibre in the small intestine might act as well through interaction with free amino acids or small peptides, thus adversely affecting absorption.

The quantity of amino acids coming available for intermediary metabolism, however, may be deduced from the apparent digestibility of the individual amino acids, irrespective of the way an increased quantity of proteins leaving the ileum is induced. Thus a practical consequence of supplying less digestible diets is, apart from possible adverse effects on the quantity of protein reaching the duodenum, a negative effect on apparent digestibility of amino acids in the small intestine. The proportion in which the amino acids are absorbed might be slightly affected as well, since an increased flow of non-protein dry matter in the small intestine was found to affect absorption of amino acids proportionally differently (van Bruchem et al., 1987). In the present experiments, with the ratio between dry matter and protein passage in the small intestine varying only slightly, proportions in which the amino acids were absorbed were not related to diets supplied. In Table 6 , the mean profile of absorbed amino acids has been compared with the profiles of milk and beef, showing that in dairy and beef cattle the availability of histidine and methionine would have to be regarded as the first limiting (semi-)essential amino acid.

\section{Acknowledgements}

The authors gratefully acknowledge Ing. L. A. Mol of the WAU Department of Field Crops and Grassland Science and Mr H. van Dijk of the WAU experimental farm 'De Ossekampen' for growing and ensiling the roughages, Messrs G. A. Bang$\mathrm{ma}$ and $\mathrm{G}$. van Gelderen for taking care of the cannulated animals and conducting the experiments, Mrs S. C. W. Lammers-Wienhoven and Messers L. J. G. M. Bongers, W. Onck and C. P. Leffering for skilled analytical assistance. In addition to Messrs A. K. Kies and R. Bremmers, Miss Marlou Bosch and Messrs I. M. Jans- 
sen and J. D. van der Klis contributed to this research program as undergraduate students.

\section{References}

Binnerts, W. T., A. Th. van 't Klooster \& A. M. Frens, 1968. Soluble chromium indicator measured by atomic absorption in digestion experiments. Veterinary Record 82: 470.

Bosch, Marlou W., I. M. Janssen, J. van Bruchem, H. Boer \& G. Hof, 1988. Digestion of alfalfa and grass silages in sheep. 1. Rates of fermentation in and passage from the reticulorumen. Netherlands Journal of Agricultural Science, 36: 175-185.

Bruchem, J. van, S. M. G. Rouwers, G. A. Bangma, S. C. W. Lammers-Wienhoven \& P. W. M. van Adrichem, 1985a. Digestion of proteins of varying degradability in sheep. 2. Amount and composition of the protein entering the small intestine. Netherlands Journal of Agricultural Science 33: 273-284.

Bruchem, J. van, L. J. G. M. Bongers, J. D. van Walsem, W. Onck \& P. W. M. van Adrichem, 1985 b. Digestion of proteins of varying degradability in sheep. 3. Apparent and true digestibility in the small intestine and ileal endogenous loss of $\mathrm{N}$ and amino acids. Netherlands Journal of Agricultural Science 33: 285-295.

Bruchem, J. van, Marlou W. Bosch, L. J. G. M. Bongers, G. A. Bangma \& P. W. M. van Adrichem, 1987. Apparent and true digestibility of amino acids in the small intestine of sheep - Effect of dry matter intake and digestibility. Proceedings of the 5th International Symposium on Protein Metabolism and Nutrition, Rostock (in press).

Harrop, C. J. F., 1974. Nitrogen metabolism in the ovine stomach. 4. Nitrogenous components of the abomasal secretions. Journal of Agricultural Science (Cambridge) 82: 249-258.

Hvelplund, T. \& J. Madsen, 1985. Amino acid passage to the small intestine in dairy cows compared with estimates of microbial protein and undegraded dietary protein from analyses in the feed. Acta Agricultura Scandinavica, Suppl. 25: 21-36.

Kwakkel, R. P., J, van Bruchem, G. Hof \& H. Boer, 1986. The in sacco degradation of crude protein and cell wall constituents in grass, alfalfa and maize silages. Netherlands Journal of Agricultural Science 34: 116-119.

Lawrie, R. A., 1979. Meat Science, Pergamon Press, Oxford.

Lindsay, J. R., J. P. Hogan, J. B. Donnelly, 1980. The digestion of protein from forage diets in the small intestine of the sheep. Australian Journal of Agricultural Research 31: 589-600.

Meyer, R. M., E. E. Bartley, C. W. Deyoe \& V. F. Colenbrander, 1967. Feed processing. 1. Ration effects on rumen microbial protein synthesis and amino acid composition. Journal of Dairy Science 50: 1327-1331.

Moore, S., 1963. On the determination of cystin as cysteic acid. Journal of Biological Chemistry 238: 235-237.

Posati, L. P., V. H. Holsinger, E. D. Devilbiss \& M. J. Pallansch, 1974. Effect of instantizing on amino acid content of nonfat dry milk. Journal of Dairy Science 57:258-260.

Satter, L. O. \& L. L. Slyter, 1974. Effect of ammonia concentration on rumen microbial protein production in vitro. British Journal of Nutrition 32: 199-208.

Siddons, R. C., D. E. Beever \& J. V. Nolan, 1982. A comparison of methods for the estimation of microbial nitrogen in duodenal digesta of sheep. British Journal of Nutrition 48: 377-389.

Storm, E., D. S. Brown \& E. R. Orskov, 1983. The nutritive value of rumen micro-organisms in ruminants. 3. The digestion of microbial amino and nucleic acids in and losses of endogenous nitrogen from the small intestine of sheep. British Journal of Nutrition 50: 479-485. 